\title{
A closer look at accounting for Islamic financial institutions
}

\author{
Nurazleena Ismail $^{1}$ and Zulkarnain Muhamad Sori ${ }^{2}$ \\ ${ }^{1}$ Senior Lecturer, Universiti Teknologi MARA, Kota Bharu, Kelantan \\ ${ }^{2}$ Professor, INCEIF, The Global University of Islamic Finance, Kuala Lumpur
}

\begin{abstract}
This paper provides a discussion of a study that examines accounting in Islamic perspectives. The discussion includes an overview of the development of Islamic finance, accounting in Islamic perspectives, and four key accounting assumptions, namely 'substance over form', 'time value of money', 'fair value' measurement and 'recognition based on probability', which serve as important guides to preparers of financial information.
\end{abstract}

Keyword: Islamic Accounting, Substance over Form, Financial Information, Fair Value, Time Value of Money

\section{AN OVERVIEW OF ISLAMIC FINANCE DEVELOPMENT}

Islamic finance has been growing quickly and its importance as an element of the global economy has increased in recent years. According to Ernst and Young's World Islamic Banking Competitiveness Report 2016, Islamic banking assets marked at US\$990 billion in 2015. The market share of Islamic banking assets in QISMUT+3 countries (QISMUT+3 is an acronym for Qatar, Indonesia, Saudi Arabia, Malaysia, United Arab Emirates, Turkey, and Kuwait, Bahrain and Pakistan) is exceeding US $\$ 920$ billion ( $93 \%$ share). Currently, there are over 600 Islamic financial institutions (IFIs) globally and Islamic banking assets are expected to reach USD3 trillion in 2020.

This growth is being achieved due to the involvement of Islamic finance in the provision of financial products and services by IFIs for Shariah (Islamic Law) approved underlying transactions and economic activities. Shariah is a basis for finance that meets the religious requirements of Muslims in line with their 'aqidah as a factor that differentiates Islamic finance from conventional finance (Tajudin, 2010). The current Shariah-compliant products have covered the full range of banking, capital markets, asset management and insurance (takaful) businesses (Azmi, 2011). Shariah complaints' products refer to product with contracts that comply with Shariah and with the prohibition of riba (which literally means 'increase' or 'addition'), maisir (speculation or gambling), and gharar (uncertainty or ambiguity), and permit risk sharing. The basic sources of Shariah are the Qur'an and the Sunnah (Thajudeen, 2012). It follows the consensus of the jurists (Qiyas) and interpreters of Islamic law ('ijmak). The principles that are held within the kingdom of Shariah are absolute, not only in the details of its transactions but also in the extent of its role in implementing the Maqasid al-Shariah. Maqasid al-Shariah or the objectives of Islamic law is one of the most important concepts in strengthening modern Islamic finance and its examination will lead to Maslahah (public interest). Therefore, the Shariah principles will ensure that Islamic finance transactions are current and transparent, and forbid involvement in illegal activities that are harmful to society. 
The alignment of accounting for Islamic finance with conventional business without compromising Shariah principles is a challenge for global groups with varied international stakeholders and extensive financial reporting. Even the Qur'an considers this issue as a serious problem, as revealed in this verse:

"O ye who believe! When ye deal with each other, in transactions involving future obligations in a fixed period of time, reduce them to writing let a scribe write down faithfully as between the parties; let not the scribe refuse to write: as Allah has thought him, so let him write. Let him who incurs the liability dictate, but let him fear his Lord Allah, and not diminish aught of what he owes. If the party liable is mentally deficient, or weak or unable himself to dictate, let his guardian dictate faithfully. And get two witnesses, out of your own men, and if there are not two men, then a man and two women, such as ye choose, for witnesses, so that if one of them errs, the other can remind her. The witnesses should not refuse when they are called on (for evidence)...." (2: 282)

This verse has led to the development of a branch of accounting literature to highlight the differences between Western and Muslim business environments (Mirza and Baydoun, 1999). As a result, the regulators of Islamic Financial Institutions (IFIs) have endorsed a major research undertaken by the International Shariah Research Academy (ISRA) to examine four key assumptions that serve as important guides to preparers of accounts and have significant impact on Islamic financial transactions: these are i) substance over form; ii) the time value of money; iii) fair value measurement; and iv) recognition based on probability (Shafii et al., 2013). In addition, this paper has reviewed the literature in relation to the topic of financial reporting in Islamic finance. Accounting theory in conventional and Islamic perspectives has also been examined.

The paper is divided into six sections. The second section illustrates accounting from an Islamic perspective. The third section provides guidelines on financial reporting for Islamic financial institutions. The fourth section provides data for the study. The fifth section discusses on analysis of the four accounting assumptions. Finally, section six concludes the paper.

\section{ACCOUNTING IN ISLAMIC PERSPECTIVES}

This section discusses accounting based on the Islamic perspective. It considers decision usefulness, stewardship, accountability, financial measurement and disclosure and presentations, and confers about them in the light of the Quran and Sunnah.

Accounting is a book-keeping system, known as "double entry". According to the known history of accounting, there are many books on "Accounting Theory", which first appeared in Italy in the 13th century, born from the hands of an Italian Priest named Luca Pacioli. He wrote the book "Summa de Arithmatica Geometria et Propotionalita" with a chapter on the "Double Entry Accounting System". The development of accounting theory subsequently improved towards the barter economy issues pertaining to understanding the meaning and scope of application of theories from the humanities and management sciences to develop accounting theory. According to Hendriksen (1977) and McDonald (1972), cited in Unegbu (2014), the development of an accounting theory should be possible. McDonald claims that such a theory must have three elements: i) encoding of phenomena to symbolic representation; ii) manipulation or combination according to rules; and iii) translation back to real-world phenomena. In addition, Unegbu (2014) stated that accounting theory is a material field in accounting. In history, accounting predates the monetary economy from the era of barter economy. Through the barter trade (exchange of goods for goods), transactions were pre-determined not only by measurement but also by exchange values. This economy system contributed inherent problems in terms of measurement inequality, was unwieldy in the variety of production and was limited by the problem of coincidence of wants.

Conventional accounting is a method generally used by the managers within a company. There are five principles underlying conventional accounting (Baydoun and Willet, 2000). These are firstly, clear separation from economic intercourse with religious considerations; secondly, the paramount importance of individual satisfaction; thirdly, profit maximization as the gauge of successful performance; fourthly, acceptance of the rule of the survival of the fittest as the best strategy, and finally, a focus on the result of the process without regard for its wider impact on the environment. It also focuses on aspects such as decision-making, the future of the company, and timeliness. This method gives the managers a better idea of the current company situation and how it will affect finances in the future. As mentioned by Remi (2006), accounting has had a significant impact on the decision-making process towards socio-economic and political development, especially in terms of recording, preparing, interpretation, auditing and management and investment. It also has 
an impact on merger and acquisition, planning, controlling and storage of business operations. Therefore, in most cases, the accounting system has allowed the equity owners to have confidence in the works and reports of the stewards. They are also entrusted with the owners' capital assets (Unegbu, 2014).

Even though conventional accounting is a well-established field, it has been criticized among scholars (Parker, 2014; Lev, 2001) in relation to accounting in Islamic views. The criticisms of conventional accounting include the following: i) externalities are not included in financial reports; ii) intangible assets cannot be measured adequately; iii) human resources and employee reporting interests are not included; iv) social interests are overlooked; v) they promote the exploitation of capitalism over labor and society; and vi) they promote the concentration of wealth and power in the hands of the rich. In light of these criticisms, Ahmed (2012) highlighted that accounting from an Islamic perspective is all about practicing positive norms and bringing self-transcendent values into everyday life, while seeking the will of God and following his orders in the form of the Prophet's (PBUH) Sunnah.

The debate between best practices in terms of accounting from the Islamic perspective or conventional accounting in the same accounting line still continues. This is due to the development of IFIs and a growing belief that the assumptions underpinning Western financial accounting systems are not compatible with Islamic beliefs and values (Haniffa and Hudaib, 2007). Ahmed (2012) added that there have been debates and discussions in literary circles around the world, particularly in Islamic nations, about how modern accounting practices can be transformed to synchronize with the Islamic philosophy of life. Conventional accounting may differ from accounting from the Islamic perspective in terms of its objectives. The objective of conventional accounting is focused on identifying economic events and transactions, whereas accounting from the Islamic perspective must identify socio-economic and religious events and transactions. It has to fulfill the ultimate accountability to Allah and to ensure fair and just financial transactions between human beings. This is because the goals of accounting and management from the Islamic perspective are not merely worldly and money-oriented. Therefore, the Accounting and Auditing Organization for Islamic Financial Institutions (AAOIFI) was established in 1990 to meet the requirements of accounting standards from the Islamic perspective. It was registered in Bahrain in 1991. The objectives of the AAOIFI are i) to develop accounting and auditing thoughts relevant to IFIs; ii) to disseminate accounting and auditing thoughts relevant to IFIs and its applications through training, seminars, publication of periodical newsletters, carrying out and commissioning of research and other means; iii) to prepare, promulgate and interpret accounting and auditing standards for IFIs; and iv) to review and amend accounting and auditing standards for IFIs.

\section{FINANCIAL REPORTING FOR ISLAMIC FINANCIAL INSTITUTIONS}

The emergence and growth of Shariah business in the modern economy has led to the rise of accounting from the Islamic perspective. This is because accounting from the Islamic perspective is based upon ethical laws originating in the Qur'an and Sunnah, requiring full disclosure of information in accordance with Shariah law and public accountability that focuses on the community that participates in exploiting resources. In order to recognize the Shariah transactions in Shariah business and IFIs, there is a need for accounting treatment and standards devoted to Shariah. This is because conventional accounting is based upon modern commercial law, which is permissive rather than ethical, with limited disclosure of information (public interest) and personal accountability (focus on individuals who control resources). Alim (2014) revealed that accounting from the Islamic perspective has to transact based on Shariah, including a profit-sharing account, a margin revenue account and an additional accounting report such as a statement of the sources and uses of Zakat funds early in its development. It also implies a Shariah-based accounting theory for the concept of Shariah transactions, called the epistemology of Shariah on accounting. There are several epistemology approaches in Islamic accounting, such as empiricism, rationalism, phenomenalism, positivism and post-modernism.

In relation to Islamic financial transactions, acceptance among the relevant players in the global Islamic finance industry is a key challenge, especially in accounting and reporting (Shafii et. al, 2013). Recently, there have been two main challengers for the role: i) the IFRS, issued by the International Accounting Standards Board (IASB); ii) the FAS issued by the AAOIFI. In September 2009, the MASB issued Statement of Principles i-1 (SOP i-1) entitled 'Financial Reporting from an Islamic Perspective'. SOP i-1 served to inform Malaysian constituents that IFRS shall apply to Islamic financial transactions in the absence of any Shariah prohibition to doing so. In addition, the MASB issued a new approved accounting framework - the Malaysian Financial Reporting Standards (MFRS) framework - in November 2011 (Shafii and Zakaria, 2013). The purpose of this issuance is in conjunction with the MASB's plan to converge with the IFRS in 2012. The MFRS framework comprises standards issued by the IASB which are effective as from January 2012. At the same time, it 
also comprises new or revised standards recently issued by the IASB, such as standards on financial instruments, consolidation, joint arrangement, fair value measurement and employee benefits, among others.

In fact, the AOSSG as a working group on financial reporting relating to Islamic finance raises issues regarding the application of IFRS to Islamic financial transactions. There are two contrasting views on how to account for Islamic financial transactions, which are i) that a separate set of Islamic accounting standards is required; or ii) that IFRS can be applied to Islamic financial transactions. The literature on accounting for Islamic financial transactions represents a spectrum of views wherein transactions can generally be accounted for using IFRS. In 2014, a study conducted by the AOSSG Islamic Finance Working Group found that many standard-setters, regulators and IFIs do not share the AAOIFI's views on accounting or what constitutes compliance with Shariah. Therefore, AAOIFI FAS are not universally accepted according to this study, which was conducted in more than 600 IFIs from 75 countries. The study indicates that IFRS are the more commonly used standards for financial reporting by IFIs. However, 24 IFIs from six countries, namely Bahrain, Jordan, Lebanon, Oman, Qatar and Sudan, asserted compliance with AAOIFI FAS. Furthermore, a study of compliance with local GAAP also found that 26 of 45 IFIs complied with differential requirements for Islamic transactions; these IFIs were from five countries, namely Bangladesh, Egypt, Indonesia, Pakistan and Yemen. The remaining IFIs, from Brunei, India, Thailand, the Philippines, Iran, Sri Lanka, Turkey, the USA and Bangladesh, did not indicate compliance with differential requirements for Islamic transactions.

In particular, analysis of various sources indicates that accounting principles generally do not contradict the Shariah. This is why most of the abovementioned countries do not accept the AAOIFI FAS but rely more on the IFRS to report their financial transactions in IFIs. Thus, four IFRS principles are used by accountants as vital guides that influence transactions for IFIs; these are i) substance over form; ii) the time value of money; iii) fair value measurement; and iv) recognition based on probability (Shafii et al., 2013).

\section{DATA}

Data for the discussion on key accounting assumptions presented in the following sections is sourced from financial statements of two IFIs that operate under two different financial reporting regimes namely the MASB (IASB based) and the AAOIFI. It is believed that IFIs that operate in a specific country like Malaysia and Bahrain would be bind by the rules and regulations promulgated by their respective regulators in the country. Thus, observing a single IFI in Malaysia and Bahrain would represent the financial reporting practices of the other Islamic banks. The financial statements of Bank Islam Malaysia Berhad (BIMB) and Bahrain Islamic Bank (BiSB) that represent the application of accounting standards issued by the MASB and the AAOIFI respectively, were downloaded from the respective IFIs website.

\section{ANALYSIS OF FOUR ACCOUNTING ASSUMPTIONS}

\subsection{Substance over form}

In order to illustrate this issue, the Institute of Chartered Accountants of Pakistan (ICAP) is resistant towards reporting the financing effect arising from trade-based transactions and has even suggested that a financing effect does not even arise (AOSSG, 2010). They mentioned that:

\footnotetext{
"In Islamic finance, (one) cannot have a transaction whose substance is different from its legal forms. In other words, if a trade transaction is not a genuine trade transaction and is just a financing transaction then it is not acceptable in Islamic finance”.
}

This means that the form and substance of the transaction must be consistent and shall not contradict one another. In the event of inconsistency between substance and form, the Shariah places greater importance on substance (Shafii et al., 2013). This is in line with the majority of scholars from the Hanafi, Maliki and Hanbali schools, which considered the intention and meanings of contracts, unless there is a legal impediment that opposes their consideration. The Shariah Advisory Council (SAC) of Bank Negara Malaysia (BNM) also has adopted the majority view of recognizing substance over form. Others believe that it is acceptable and would benefit users more to show the economic substance of an Islamic financial transaction. Information about legal form may be relegated to the notes to the financial statements. However, Shafi'i scholars favored the principles of form over substance. The 
evidence shows that there are those who believe that the recognition and measurement of an Islamic financial transaction should give prominence to its legal form to differentiate it from a perceived conventional equivalent. It claims that substance over form is 'an unconcealed violation of Shariah'.

The diversity of reporting practices is evident from our analysis on the IFIs financial reporting practices. Analysis of financial reporting on leasing transactions reveals that IFIs that adopted the MASB (IASB based) accounting standards reported leased asset consistent with the 'substance over form' principle as shown in Figure 1 below. Leased assets (Al-Ijarah) are not recognized as the bank's assets; instead, they are disclosed as financial assets under the Al-Ijarah contract. This indicates that economic substance of the lease transaction is recognized as more important than the legal form. On the other hand, IFIs that adopted the AAOIFI accounting standards used the 'form over substance' principle as indicated in Figure 2 below.

\begin{tabular}{|c|c|c|c|c|c|c|c|c|c|}
\hline \multicolumn{10}{|c|}{ Financing, advances and others } \\
\hline \multicolumn{10}{|c|}{ (a) By type and Shariah contract } \\
\hline & $\begin{array}{r}\text { Bai' } \\
\text { Bithaman }\end{array}$ & & Bai & & $\begin{array}{r}\text { Ijarah } \\
\text { Muntahiah }\end{array}$ & $\begin{array}{r}\text { Ijarah } \\
\text { Thumma }\end{array}$ & & & \\
\hline $\begin{array}{l}\text { Group and Bank } \\
31 \text { December } 2015\end{array}$ & $\begin{array}{r}\text { Ajil } \\
\text { RMY000 }^{\prime}\end{array}$ & $\begin{array}{r}\text { Murabahah } \\
\text { RM'000 }\end{array}$ & $\begin{array}{l}\text { Al-Inah } \\
\text { RM'000 }\end{array}$ & $\begin{array}{r}\text { At-Tawarruq } \\
\mathbf{R M} \mathbf{Y}^{\prime} \mathbf{0 0 0}\end{array}$ & $\begin{array}{r}\text { Bit-Tamleek } \\
\text { RM'000 }\end{array}$ & $\begin{array}{r}\text { Al-Bai } \\
\text { RM'000 }\end{array}$ & $\begin{array}{l}\text { Istisna' } \\
\text { RM'000 }\end{array}$ & $\begin{array}{r}\text { Ar-Rahnu } \\
\text { RM'000 }\end{array}$ & $\begin{array}{r}\text { Total } \\
\text { RM'000 }\end{array}$ \\
\hline \multicolumn{10}{|l|}{ At amortised cost } \\
\hline Cash line & - & - & 62,300 & 997,097 & - & - & - & - & $1,059,397$ \\
\hline \multicolumn{10}{|l|}{ Term financing } \\
\hline House financing $\wedge$ & $4,851,790$ & - & - & $6,628,865$ & - & - & 62,580 & - & $11,543,235$ \\
\hline Syndicated financing & 8,603 & - & 164,301 & $1,021,805$ & - & 127,399 & - & - & $1,322,108$ \\
\hline Leasing financing & - & - & - & - & 81,223 & 1,769 & - & - & 82,992 \\
\hline Bridging financing & - & - & - & - & - & - & 87,630 & - & 87,630 \\
\hline Personal financing & - & - & 82,054 & $10,247,851$ & - & - & - & - & $10,329,905$ \\
\hline Other term financing & $2,583,462$ & 685,973 & 18,444 & $5,385,013$ & - & - & 1,762 & - & $8,674,654$ \\
\hline Staff financing & 96,919 & 1,515 & - & 68,007 & - & - & 16,401 & - & 182,842 \\
\hline Credit cards & - & - & 12,695 & 430,848 & - & - & - & - & 443,543 \\
\hline Trade bills discounted & - & $1,139,827$ & - & - & - & - & - & - & $1,139,827$ \\
\hline Trust receipts & - & 20,210 & - & - & - & - & - & - & 20,210 \\
\hline \multirow[t]{2}{*}{ Pawn broking } & - & - & - & - & - & - & - & 73,883 & 73,883 \\
\hline & $7,540,774$ & $1,847,525$ & 339,794 & $24,779,486$ & 81,223 & 129,168 & 168,373 & 73,883 & $34,960,226$ \\
\hline
\end{tabular}

Figure 1: Extract BIMB's Financial Statements

As shown in Figure 2, the BiSB recognized leased assets as the bank's assets and subjected to normal provision for depreciation and assets impairment. This indicates that the bank claims ownership over the leased assets, which explains the importance of legal form over economics substance of the transaction ${ }^{1}$.

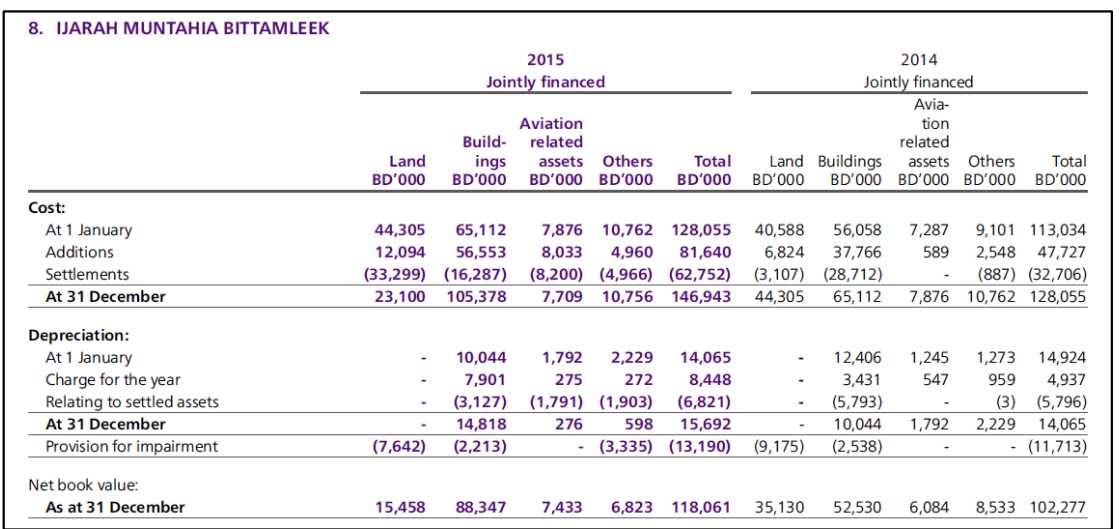

Figure 2: Extract BiSB's Financial Statements

\subsection{Time value of money}

With regard to the time value of money concept, where a transaction involves time deferment, the asset (liability) is carried at the present discounted value of the future net cash inflow (outflow) that the transaction is expected to generate in the normal course of business. The application of the time value

\footnotetext{
1 the AAOIFI only recognized operating lease and rejected the financial lease in their accounting standards.
} 
of money is permissible only for exchange contracts that involve deferred payment and is strictly prohibited in loan transactions (Qard). This is in line with Shafii et al. (2013), who stated that the concept of time value of money is acceptable in contracts of exchange whereby the deferred price will be higher than the spot price in order to uphold the element of justice ('adl) between contracting parties. However, it is not acceptable to charge an extra sum for the deferred payment of a qard (loan). Therefore, this principle is only applicable in exchange contracts, not in loan contracts. This is because interest-based transactions are prohibited in Islamic finance.

In fact, Islamic law recognizes the selling price differences between a cash payment sale and a deferred payment sale such as Murabahah (ISRA, 2011). The majority of Muslim jurists agree that a higher price can be charged in a deferred payment sale due to the time factor involved in determining the value of the contracted item. Also, it can be said that Shariah does not completely rule out the concept of time value of money. This is evidenced by the fact that Islam does not prohibit any increment in a sale contract to be paid at a future date. This is because a repayment of a financing involves paying more than the principal to compensate for the time involved. Hence, the time value of money is accepted for the purpose of pricing of goods/usufruct only and not for pricing of money or debts (Ayub, 2007). So, what is not permissible is its use in compounding the interest for the lending of money.

Analysis of financial statements of Bank Islam Malaysia Berhad reveals the application of the time value of money concept as shown in Figure 3 below. However, there is no disclosure on the concept by the BiSB.

\subsection{Leased assets - Finance lease}

Leases in terms of which the Group or the Bank assumes substantially all the risks and rewards of ownership are classified as finance leases. Upon initial recognition, the leased asset is measured at an amount equal to the lower of its fair value and the present value of the minimum lease payments. Subsequent to initial recognition, the asset is accounted for in accordance with the accounting policy applicable to that asset.

Figure 3: BIMB's Disclosure on the use of Time Value of Money

\subsection{Fair value measurement}

Fair value refers to the amount at which an asset could be bought or sold in the current market (Shafii et al., 2013). Islam emphasizes fair dealing and just commercial transactions. However, there are various ways of manipulating market conditions to affect the market price. This indicates that Islamic commercial transactions must be carried out based on fair value.

There are two prohibited sales namely Talaqqi al-rukban (meeting caravans before they reach the market) and najsh (false bidding). The Prophet (PBUH) prohibited such sales in order to prevent city-dwellers from meeting caravans in order to buy from them before they reach the market and find out the prevailing price for their goods. He also said "Do not intercept goods before they are offloaded in the market". If this does occur, the importer of the goods has the option to annul the sale once he reaches the market and finds out the going price (ISRA, 2010). However, jurists have different views on the wisdom behind this prohibition. Some of them say that it is to prevent harm to the importer; some say it is for the benefit of the market and residents of the city; and some say that it is for the benefit of both the importer and the people. Others say that it is in order to prevent deception of the importer through false information about the market prices.

A similar consideration is operative in the prohibition of najsh, which is where a person bids in an auction without intending to actually buy, merely to drive up the price (ISRA, 2010). This is prohibited by consensus. It can occur without the seller's knowledge, in which case the sin is restricted to the bidder who drove up the price. However, if both of them knew, then they share in the sin. In fact, there are clear examples of prohibition of talaqqi al-rukhban and najsh incorporation of the fair value principle in Islamic financial transactions. A review of the classical fiqh literature reveals many instances where this principle was given consideration by jurists in deducing rulings. For example, the fair value benchmarked with the market price was used to determine the subsistence (nafaqah) of the agent-manager while travelling in a mudarabah contract. Scholars also agree on the role of experts and the use of estimation techniques in determining the fair value when there is no clear market price for a commodity. Nevertheless, controversy apparently prevails on the use of discount rates within the estimation techniques. 
As shown in Figure 4 below, the BIMB used market information as well as the valuation techniques to estimate market value of assets or liabilities. On the other hand, the BiSB used market information and in the event there is no market information, they will use market information of similar item. If both of the above information are not available, then, historical cost would be utilized as illustrated in Figure 5 below.

\subsection{Fair value measurements}

'Fair value' is the price that would be received to sell an asset or paid to transfer a liability in an orderly transaction between market participants at the measurement date in the principal or in its absence, the most advantageous market to which the Group has access at that date. The fair value of a liability reflects its non-performance risk.

When available, the Group measures the fair value of an instrument using the quoted price in an active market for that instrument. A market is regarded as active if transactions for the asset or liability take place with sufficient frequency and volume to provide pricing information on an ongoing basis.

If there is no quoted price in an active market, then the Group uses valuation techniques that maximise the use of relevant observable inputs and minimise the use of unobservable inputs. The chosen valuation technique incorporates all of the factors that market participants would take into account in pricing a transaction.

Figure 4: BIMB's Disclosure on Fair Value

\section{k. Determination of fair value}

For investments traded in organised financial markets, fair value is determined by reference to quoted market bid prices at the close of business on the consolidated statement of financial position date.

For investments where there is no quoted market price, a reasonable estimate of the fair value is determined by reference to the current market value of another instrument, which is substantially the same or is based on the assessment of future cash flows. The cash equivalent values are determined by the Group at current profit rates for contracts with similar terms and risk characteristics.

Investments at fair value through equity where the Bank is unable to determine a reliable measure of fair value on a continuing basis, such as investments that do not have a quoted market price or other appropriate methods from which to derive reliable fair values, are stated at cost less impairment allowances.

Figure 5: BisB's Disclosure on Fair Value

\subsection{Recognition based on probability}

Probability is where the degree of uncertainty that the future economic benefits associated with the transaction will flow to or from the licensed person is considered in reference to the recognition criteria. The principle of probability in accounting and financial reporting from the Shari'ah perspective refers to the practice of recording a transaction even though the contract's effects have not yet been entirely concluded (Shafii et al., 2013). In this regard, assets will be recorded once there is a probability of inflow of economic resources, while liability will be recorded once there is a probability of outflow of economic resources due to current obligations and once its amount can be estimated with reasonable certainty. The examples of recognition based on probability in an IFI are: i) recognizing a liability for expected payments to mudarabah account holders; ii) recognizing impairment of financial assets based on an impairment model; iii) recognizing mudarabah receivables using the expected rate of profit; and iv) recognizing income and expenses based on expected future cash flows.

It is recognized that certainty is the highest level of confidence in Islam. It should be noted that jurists have established certain parameters in adopting the concept of probability in fiqh. The SAC of BNM also resolved that the application of the probability principle in Islamic financial reporting is 
permissible, as it does not contradict the general fiqh principles. Other fatwa-issuing bodies have not yet issued any specific fatwa on the principle.

Figure 6 illustrates the approach taken by the BIMB in applying the principles of probability, while, Figure 7 shows the BiSB disclosure on principle of probability. It is evident that both of the regimes i.e. MASB and AAOIFI accepted and implemented the concept.

\section{(d) Use of estimates and judgement}

The preparation of the financial statements requires management to make judgements, estimates and assumptions that affect the application of accounting policies and the reported amounts of assets, liabilities, income and expenses. Actual results may differ from these estimates. Estimates and underlying assumptions are reviewed on an ongoing basis. Revisions to accounting estimates are recognised in the financial statements in the period in which the estimates are revised and in any future periods affected.

Figure 6: BIMB's Accounting Policy on Estimates and Judgement

\section{aa. Revenue recognition Murabaha receivables}

Income is recognised by proportionately allocating the attributable profits over the deferred period whereby each financial period carries its portion of profits irrespective of when cash is received. Income related to accounts that are 90 days overdue is excluded from the consolidated statement of income.

Figure 7: BiSB's Accounting Policy on Revenue Recognition

This section has discussed the Financial Reporting assumptions for Islamic Financial Institutions. It has considered four assumptions: substance over form, the time value of money, fair value measurement and recognition based on probability. The next section will conclude the paper.

\section{CONCLUSION}

This section will provide a summary and the key findings of the paper based on an in-depth review and discussion. Financial reporting in Islamic society should be more detailed as compared to the current form of reporting that is prevalent in Western societies, and should consider moral values. There should be an emphasis on transparency, while manipulation of the values of assets should be avoided. As well as an emphasis on the profit and loss statement, the balance sheet and the cash flow statement, a considerable amount of further information should be provided. This could include a value-added statement and disclosure about the firm's social performance activities. The reports are also likely to include information about zakat, qard and charitable distributions. Items that involve the use of interest will be excluded.

Differences of opinion on how to account for Islamic financial transactions have led to divergent treatments of various transactions in various jurisdictions. Thus, it is necessary to enhance cross-border comparability by standardizing the reporting of Islamic transactions. While this could easily be achieved by the use of the IFRS, it would result in the reporting of the economic substance of transactions and of their financing effect. This may not appeal to certain stakeholders. Therefore, the challenge to standard-setters and stakeholders is to enhance the cross-border comparability of Islamic financial transactions, while being mindful of religious sensitivities. Although the IFRS are internationally accepted, there is resistance by those who believe that some IFRS principles are irreconcilable with their interpretation of Shariah. As a result, a separate financial reporting framework for Islamic financial transactions is warranted. However, the Malaysian regulators have issued directive to the IFIs to comply with the MASB standards due to the key accounting principles are complied with the Shariah requirements. 


\section{REFERENCES}

1. AAOIFI. (1996). Accounting and auditing standards for Islamic financial institutions. Manama, Bahrain: Accounting and Auditing Organization for Islamic Financial Institutions.

2. ACCA \& KPMG,. (2012, November). Global alignment:bringing consistency to reporting of Islamic finance through IFRS. The Association of Chartered Certified Accountants .

3. Ahmed, A. A. (2012). Accounting in Islamic perspective: A timely opportunity a timely challenge. $A S A$ University Review, 11-31.

4. Alim, M. N. (2014). The development of Shari'ah accounting: epistemology perspective. European Scientific Journal , 110-117.

5. AOSSG Islamic Finance Working Group. (2015). Financial reporting by Islamic financial institutions: a study of financial statements of Islamic financial institutions. Asian-Oceanian Standard-Setters Group.

6. AOSSG Working Group. (2010). Financial reporting issues relating to Islamic finance. AsianOceanian Standard-Setters Group.

7. Ayub, M. (2007). Understanding Islamic Finance. Asia: John Wily and Sons (Asia) Pte Ltd.

8. Azmi, M. F. (2011). Shari'ah Challenge. Global Islamic Finance Team .

9. Bank Negara Malaysia. (2013, June 28). Financial reporting for Islamic banking institutions. Islamic Banking and Takaful Department, pp. 1-29.

10. Baydoun, N., \& Willett R. (2000), Islamic and accounting: ethical issues in the presentation of financial information. Accounting, Commerce \& Finance: The Islamic Perspective, 1-25.

11. Haniffa, R., \& Hudaib, M. (2007). Exploring the ethical identity of Islamic banks via communication in annual reports. Journal of Business Ethics, 76(1), 97-116.

12. ISRA. (2011). Islamic Financial System: Principles and Operations . Kuala Lumpur: International Shari'ah Research academy of Islamic Finance.

13. ISRA. (2010). ISRA Compendium for Islamic financial terms. Kuala Lumpur: International Shari'ah Research Academy of Islamic Finance.

14. Lev, B. (2001). Intangibles: Management, measurement, and reporting. Washington, D.C. Brookings Institution Press

15. Malaysia Accounting Standards Board. (2009). Financial reporting from Islamic perspective. International Accounting Standards Committee Foundation .

16. MASB. (2011). The conceptual framework for financial reporting. IFRS Foundation.

17. Mirza, M., \& Baydoun, N. (1999). Accounting policy choice in an interest-free environment. Working Paper No. 1999-014.

18. Parker, L. (2014). Constructing a research field: a reflection on the history of social and environmental accounting. Social and Environmental Accounting Journal, 34(2), 87-92.

19. Remi, A., (2006), Advanced financial accounting, Second Edition, Lagos Master Stroke Consulting.

20. Shafii, Z., \& Zakaria, N. (2013). Adoption of international financial reporting standards and international accounting standards in Islamic financial institutions from practitioners' viewpoint. Middle-East Journal of Scientific Research, 42-49.

21. Shafii, Z., Zakaria, N., Shaharuddin, A., Sairally, B. S., Khir, M. F., Hussain, L., et al. (2013). An apparaisal of the principles underlying international financial reporting standards: A Shar'ah Perspective. ISRA Research Paper 54/2013, 1-36.

22. Tajudin, A. A. (2010). Overview of Islamic finance. Kuala Lumpur, Malaysia: Bank Islam.

23. Thajudeen, K. S. (2012). Maqasid al-Shariah is one of the very important Shariah aspects in Islamic Finance. INCEIF .

24. Unegbu, A. O. (2014). Theories of accounting: evolution \& developments, income-determination and diversities in use. Research Journal of Finance and Accounting , 1-15. 